\title{
Effects of cattle grazing on blue oak seedling damage and survival
}

\author{
LILLIAN M. HALL, MELVIN R. GEORGE, DOUGLAS D. MCCREARY, AND THEO- \\ DORE E. ADAMS
}

Senior, second, and fourth authors are post-graduate researcher, extension range and pasture specialist, and extension wildlands specialist, respectively, Dept. of Agronomy and Range Science, University of California, Davis, Calif. 95616-8515; third author is extension natural resource specialist, University of California Cooperative Extension. Browns Valley, Calif. 95918.

\begin{abstract}
Cattle graxing has been suggested as a principal cause for poor oak recruitment in California's hardwood rangelands. This study evaluated the effects of stock density and season of grazing on blue oak (Quercus douglasiï H. \& A.) establishment. In December 1989, seven hundred and twenty blue oak seedlings were planted on 3-m centers in 30 plots in 3 annual grassland pastures at the Sierra Foothill Research and Extension Center east of Marysville, Calif. The treatments consisted of 3 seasons $X 3$ stock densities plus 1 nongrazed control. During January, April, and July of 1990, steers and heifers $(\bar{x}=318 \mathrm{~kg})$ were allowed to graze 1 plot per week at low, medium, and high stock densities $(2.5,7.5$, and 15.0 head/ha, respectively). Control plots were used to monitor wildlife browsing. One half of all seedling sites received an application of glyphosate prior to transplanting to eliminate grass competition. Browsing and trampling damage were estimated at the end of each treatment. Total damage (sum of browsing and trampling damage), browsing damage, trampling damage, and survival to April 1991 were significantly different for the 9 season and stock density treatments $(p<0.05)$. Spring and summer grazing tended to be most damaging and resulted in the lowest survival rates. Within each season total damage increased with stock density but survival did not change significantly. Weed control around oak seedlings had no apparent effect on total damage or survival. There were significant differences in browsing damage between seasons but not between control and grazed plots within seasons $(p<0.05)$. Survival in ungrazed plots was not significantly different $(p<0.05)$ from the spring and summer grazed plots. Consequently, the contribution of wildlife to reduced blue oak seedling survival in grazed oak woodlands should not be underestimated.
\end{abstract}

Key Words: browsing, foothill/oak woodland, grazing management, recruitment

California's hardwood rangelands, of which oaks are a major component, occupy over 2.8 million hectares and are the source of 28\% of the state's range forage (Forest and Rangeland Resources Assessment Program 1988). The future of oaks has become the focus of public scrutiny in recent years due to their declining numbers and concern about poor natural recruitment. Since the turn of the century, there have been reports that several native species were not regenerating sufficiently to maintain existing stand densities or species distribution (Sudworth 1908). Several authors have recently confirmed that blue oak is regenerating poorly in certain areas of the state (Mayer et al. 1986, Muick and Bartolome 1986, Bolsinger 1988).

With the recent concern over the fate of oaks in California's

Manuscript accepted 28 Feb. 1992. hardwood rangelands, livestock have been identified as a probable cause of poor oak recruitment (Twisselmann 1967, Franco 1976, Griggs 1986). Livestock are one of many mammalian predators of oak seedlings and acorns. Other authors discount the primary importance of cattle in limiting oak recruitment. Griffin (1976) noted that at the Hastings Reservation in California, where livestock grazing has been absent for 37 years, valley oak saplings were still rare due to deer and other animals.

The objective of this study was to determine the impact of different seasons and intensities of grazing on blue oak seedling damage and survival.

\section{Methods and Materials}

The study was conducted on the University of California's Sierra Foothill Research and Extension Center (SFREC), $31 \mathrm{~km}$ east of Marysville in Yuba County, Calif. This lower Sierra Nevada foothill location is approximately 330 m elevation at $3914^{\prime} \mathrm{N} 12118^{\prime}$ W. An average of 750 to $900 \mathrm{~mm}$ of rainfall is received between mid-October and late April in a typical Mediterranean climate. Total precipitation during the project (1 September 1989 to 30 August 1990) was $678 \mathrm{~mm}$. The soil type on the study site s a Sobrante gravelley loam (mixed thermic Mollic Haploxeralf). Experimental pastures 1 and 2 were on rolling terrain (8-15\% slope) while pasture 3 was steeper (15-50\% slope).

The vegetation is typical of the lower foothill oak ((Quercus spp.) woodlands that have been cleared of trees (Quercus douglasii H. and A., Q. wislizenii A. DC. and Pinus sabiniana Dougl. Ex D. Don) and shrubs (Arctostaphylos viscida Parry, Ceanothus cuneatus (Hook) Nutt., Cercocarpus betuloides Nutt., and Rhus diversiloba T.\& G.) to increase range forage production. In the experimental pastures, the plant community included annual grass species such as soft chess (Bromus mollis L.), ripgut brome ( $B$ diandrus Roth), red brome (B. rubens L.), annual fescue (Vulpia myuros (L.) C.C. Gmel.), wild oats (Avena fatua L.) medusahead (Taeniatherum asperum Nevskii), and dogtail (Cynosurus echinatus L.); perennial Hardinggrass (Phalaris tuberosa var. stenoptera (Hack.) A. Hitchc.), and forbs such as filaree (Erodium spp.) and rose clover (Trifolium hirtum All.).

Blue oak seedlings used in this study were produced from acorns collected from 6 blue oak trees at the Dye Creek Ranch, south of Red Bluff, Calif., in late September, 1988. The acorns were placed in cold storage until December, when they were sown into $38 \mathrm{~mm} X$ 203-mm paper sleeves. A standard potting mixture containing peat moss, vermiculite, and fir bark was used. The seedlings were grown in a greenhouse from December 1988 to May 1989 and then placed in a lathhouse in Los Molinos, Calif., until October 1989, when they were transported to SFREC and kept outside until transplanting. 
In December 1989, 24 one-year-old blue oak seedlings were planted into each of thirty $17 \times 30-\mathrm{m}$ plots, 10 in each pasture. That arrangement provided 3 replications of 10 treatments. The treatments consisted of 3 seasons $\times 3$ stock densities plus 1 nongrazed control. The nongrazed control was closed to grazing by livestock but to accessible deer (Odocoileus hemionus) and other wildlife. The 10 treatments were randomly assigned to plots in each replicate. Plots were separated from the pasture by portable electric fencing.

In each plot, 24 seedlings were planted on $3-\mathrm{m}$ centers in $90 \mathrm{~cm}$ deep holes in which a 21-g slow-release fertilizer tablet (20-10-5) had been placed. Prior to transplanting, 12 of the 24 seedling sites in each plot were randomly chosen to receive an application of glyphosate, at the rate of $2.2 \mathrm{~kg} \mathrm{ha}^{-1}$ to eliminate grass competition. Glyphosate was applied to a circle of $45 \mathrm{~cm}$ radius around the seedling site.

During winter (17 January-6 February 1990) and spring (3-23 April 1990) 3 steers grazed each pasture. These were replaced in summer (26 June-16 July 1990) by heifers. The steers and heifers averaged $318 \mathrm{~kg}$ live weight when they entered the study. The animals were assigned to pastures and each group grazed the same pasture in each cycle.

Stock density in each season was increased in weekly increments by reducing pasture size with portable electric fencing. In week 1 of each season (low stock density), animals in each pasture had access to 1.2 ha that included an oak seedling plot for a stock density of 2.5 head ha ${ }^{-1}$. At the beginning of the second week (medium stock density), the area was reduced to 0.4 ha for a stock density of 7.5 head $\mathrm{ha}^{-1}$. The pasture was further reduced at the beginning of the third week (high stock density) to 0.2 ha for a stock density of 15 head $\mathrm{ha}^{-1}$. A new oak plot was available each week.

Seedlings were numbered (1-24) according to their location in each plot so that seedling damage and survival could be monitored. Each seedling's height was measured before and after grazing. Seedlings were counted as browsed if a stem was visibly severed or there was a measurable decrease in height. Seedlings were counted as trampled if they were broken. In winter and spring, broken seedlings were often found in depressions created by hoof impact on wet soils. A few seedlings that were both browsed and trampled were counted as trampled. Seedling survival was determined in April 1991 by counting seedlings that produced new leaves.

At the end of each season's trial, the cattle were removed from the fields until the next season. During periods of no grazing, all seedlings were covered by aluminum screen cages to prevent damage by deer and other wildlife.

Differences between seasons, stock densities, treatment (season $X$ stock density) and the herbicide sub-factor were analyzed as a completely randomized-split plot design using analysis of variance. Least significant differences (LSD) were calculated where significant collective browsing and trampling effects were detected. Differences were considered significant at the $p<0.05$ level. Survival counts expressed as proportions were subjected to arcsine transformation prior to analysis of variance and mean separation (Little and Hills 1978).

\section{Results and Discussion}

\section{Season and Stock Density Treatments}

Analysis of variance showed significant differences between treatments for total damage, browsing damage, trampling damage and survival to April 1991 (Table 1). Total damage was the sum of grazing and trampling damage. Weed control around oak seedlings had no apparent effect on total damage or survival to April 1991 (Table 2). Of the $26 \%$ that survived $14 \%$ were herbicide treated and $12 \%$ were not treated.

Mean separation (LSD, $p<0.05$ ), revealed that total damage
Table 1. Seedling damage $(\%)$ and survival $(\%)$ and $(\%)$ to April 1991 for blue oak seedlings in plots grazed during the 1989-90 growing season.

\begin{tabular}{|c|c|c|c|c|c|}
\hline \multicolumn{2}{|c|}{ Treatments } & \multicolumn{4}{|c|}{ Damage } \\
\hline Season & $\begin{array}{l}\text { Stock } \\
\text { density }\end{array}$ & Browsed & Tramp & Total & Surival \\
\hline $\begin{array}{l}\text { Winter } \\
\text { Winter } \\
\text { Winter } \\
\text { Spring } \\
\text { Spring } \\
\text { Spring } \\
\text { Summer } \\
\text { Summer } \\
\text { Summer }\end{array}$ & $\begin{array}{l}\text { low } \\
\text { medium } \\
\text { high } \\
\text { low } \\
\text { medium } \\
\text { high } \\
\text { low } \\
\text { medium } \\
\text { high }\end{array}$ & $\begin{array}{l}6 \mathrm{f} \\
25 \mathrm{def} \\
19 \mathrm{def} \\
39 \mathrm{cde} \\
61 \mathrm{abc} \\
79 \mathrm{ab} \\
54 \mathrm{bcd} \\
74 \mathrm{ab} \\
89 \mathrm{a}\end{array}$ & $\begin{array}{c}6 \mathrm{~cd} \\
13 \mathrm{bc} \\
33 \mathrm{a} \\
1 \mathrm{~d} \\
3 \mathrm{~d} \\
14 \mathrm{~b} \\
3 \mathrm{~d} \\
0 \mathrm{~d} \\
4 \mathrm{~d}\end{array}$ & $\begin{array}{l}\%) \\
12 \mathrm{f} \\
38 \mathrm{e} \\
52 \mathrm{cde} \\
40 \mathrm{de} \\
64 \mathrm{bc} \\
93 \mathrm{a} \\
57 \mathrm{bcd} \\
74 \mathrm{~b} \\
93 \mathrm{a}\end{array}$ & $\begin{array}{l}46 \mathrm{a} \\
43 \mathrm{a} \\
50 \mathrm{a} \\
20 \mathrm{bcd} \\
22 \mathrm{bc} \\
29 \mathrm{~b} \\
7 \mathrm{~d} \\
7 \mathrm{~d} \\
12 \mathrm{dc}\end{array}$ \\
\hline
\end{tabular}

Means in the same column followed by the same letter are not significantly different at $p<0.05$.

Table 2. Seedling damage (\%) and survival (\%) to April 1991 for blue oak seedlings that received weed control or no weed control during the 1989-90 growing season.

\begin{tabular}{lcccc}
\hline & \multicolumn{3}{c}{ Damage } & \\
\cline { 2 - 4 } Treatment & Browsed & Trampled & Total & Survival \\
\hline & 25 & 4 & 29 & 14 \\
Herbicide & 24 & 4 & 28 & 12 \\
No herbicide & N.S. & N.S. & N.S. & N.S. \\
F Test $(p<0.05)$ &
\end{tabular}

increased with stock density. Winter grazing at low stock densities was least damaging of the treatments while spring or summer grazing at high stock densities was most damaging. The lowest stock density used in this study $\left(2.5\right.$ head ha $\left.{ }^{-1}\right)$ exceeded those normally used ( 1 head per 1 to $2 \mathrm{ha}$ ) on foothill ranches that are continuously grazed during the winter and spring grazing season. However, the stock densities used in this study were representative of those where rotational grazing is practiced. Because the pastures used in this study have been cleared of oak trees, care should be taken in extrapolating these results to pastures with oak trees. Damage to oak seedlings under oak trees may be greater than measured in this study because cattle are often attracted to oak trees by higher forage levels, differing species composition, shade (Duncan and Clawson 1980), higher forage quality (Frost, McDougald and Demment 1991), and acorns (Borchert et al. 1989).

During spring and summer, trampling damage was a minor contributor to total damage while trampling accounted for more than one-third of the total damage in winter. We assume that trampling is a random event that would increase as density increases. Low winter forage levels may increase foraging activity by livestock, resulting in more complete utilization of a pasture and therefore greater chances for a random trampling event. More complete utilization coupled with soft, wet soils may explain winter trampling.

Winter browsing damage was significantly lower than spring and summer browsing at medium and high stock densities. Spring browsing damage at all stock densities was much higher than anticipated. It was thought that damage to oak seedlings would diminish as green forage quantity increased. However, the steers appeared to have been attracted to patches of rose clover in the oak seedling plots, resulting in greater browsing damage.

Heavy summer browsing damage suggests that when annual grasses and forbs are dry and less palatable, cattle may choose oak seedlings because they are the only green vegetation in the pastures during the summer months. Longhurst et al. 1979 found that the browse component of sheep diets increased during the summer 
months. Wagnon (1963) found that cattle spent time browsing woody vegetation at San Joaquin Experimental Range from late spring through mid winter. During most of the spring forage growing season, cattle spent little or no time browsing woody vegetation.

Within each season of grazing, seedling survival to April 1991 (end of second growing season) was not influenced by stock density. Seedling survival to April 1991 was significantly greater for the winter treatments than all other treatments. Seedling survival for winter grazing treatments may be due to higher soil moisture. Browsing and trampling damage to seedling roots may be less in the more pliable wet winter soils, or remaining undamaged roots may be able to grow and replace damaged roots during the remainder of the growing season. Several seedlings that were pushed into the soil by trampling in January 1990 were observed to survive to April 1991. Seedlings damaged during spring had less time to replace damaged roots. Poor summer survival may have been the result of extensive root tearing in dry, inflexible soil combined with inadequate soil moisture for root growth.

Yearly variation in rainfall, temperature, severity of summer drought, late spring soil moisture depletion, and seedling predator populations may influence the blue oak seedling damage and survival determined in this study. Borchert et al. (1989) report that blue oak seedling recruitment is affected by rainfall, temperature, acorn survival, and predation. Gordon et al. (1989) and Welker and Menke (1990) found that rapid soil water depletion by annual grasses reduced blue oak seedling survival near the onset of the summer dry season. The impact of deer and other wildlife on oak seedling survival has been reported by Griffin 1976 and Adams et al. (1992). Wildlife populations are presumed to fluctuate and therefore vary in their yearly impacts on oak seedling survival.

This study reports direct influence of livestock grazing on seedling damage and survival. Livestock may also have indirect influences on seedling survival. Welker and Menke (1990) report a short-term increase in blue oak seedling water potential following defoliation. However, increased seedling water potential was short lived because associated annual grasses rapidly deplete soil water. Gordon et al. (1989) found that oak seedlings growing in the absence of annual grasses had higher soil water potentials, greater dry weights, and longer growing seasons than oak seedlings growing in association with annual grass. In this study and throughout its range, blue oak seedlings must establish and survive in association with annual grasses. We speculate that close grazing of annual grasses could reduce rapid soil water depletion that is common at the end of the growing season. Georgiadis et al. (1989) report that the growing season of grazed plants in the Serengeti may be extended where the pasture species present receive the same reduction in transpirational surface. If closely grazed annual grasses deplete soil water less quickly than those that are light or moderately grazed, a grazing regime beneficial to blue oak seedling survival may be attainable.

\section{Comparison of Grazed and Ungrazed Plots}

Browsing of oak seedlings in ungrazed control plots and grazed plots was compared for each season of grazing (Table 3). Analysis of variance revealed significant differences between seasons but not between control and grazed plots within seasons. Damage was greatest during the summer season but there was no difference in browsing damage between grazed plots and those protected from cattle grazing. Damage was least in the winter season with no difference between the cattle grazed plots and those protected from cattle grazing. Damage was greatest in the summer grazed and ungrazed plots and least in the winter grazed and ungrazed plots.

Since there was only 1 control plot per replicate, survival data of ungrazed control plot seedlings could not be separated into seasonal groups. Survival to the second growing season (April 1991)
Table 3. Blue oak browsing damage (\%) in plots that were grazed or ungrazed during winter, spring or summer.

\begin{tabular}{lc}
\hline Treatment & Browsing \\
\hline & $(\%)$ \\
Winter-grazed & $17 \mathrm{~d}$ \\
Winter-control & $0 \mathrm{~d}$ \\
Spring-grazed & $59 \mathrm{bc}$ \\
Spring-control & $46 \mathrm{c}$ \\
Summer-grazed & $72 \mathrm{ab}$ \\
Summer-control & $85 \mathrm{a}$ \\
\hline
\end{tabular}

Numbers followed by the same letter are not significantly different at $p<0.05$.

Table 4. Blue oak survival one year following winter, spring, or summer grazing compared to an ungrazed control.

\begin{tabular}{lc}
\hline Treatment & Survival \\
\hline & $(\%)$ \\
Winter-grazed & $46 \mathrm{a}$ \\
Spring-grazed & $24 \mathrm{~b}$ \\
Summer-grazed & $9 \mathrm{~b}$ \\
Control & $15 \mathrm{~b}$ \\
\hline
\end{tabular}

Numbers followed by the same letter are not significantly different at $p<0.05$. Survival percentages were subjected to arscine transformation prior to ANOVA and mean separation.

was greatest for winter grazed plots (Table 4). Survival in the ungrazed control and spring and summer grazed plots was not significantly different $(p<0.05)$.

It was not possible to differentiate between cattle and wildlife browsing in the grazed plots. The control plots were not accessible to cattle but were accessible to resident wildlife. A high potential for deer browsing is confirmed by frequent sightings, deer pellets, and hoof prints. However, other wildlife, including pocket gophers (Thomomys bottae Eydoux \& Gervais), rabbits (Sylvilagus spp.), jackrabbits (Lepus californicus Gray), and grasshoppers (Melanoplus devastator Scudder) probably contributed to total seedling damage recorded as browsing. Within each season, browsing damage between grazed and control plots was not significantly different $(p<0.05)$, suggesting that for this site the potential for oak seedling damage by wildlife is just as great as that from grazing cattle.

While several researchers have implicated browsing by livestock as a cause of reduced oak recruitment, deer and other vertebrates and invertebrates are also implicated (Adams et al. 1992). Griggs (1986) found a slightly lower frequency of Englemann oak (Quercus englemannii) seedlings in grazed than ungrazed pastures. Griggs also noted that cattle appear to eat the seedlings because they are mixed in with forage grasses, rather than seeking them out because of higher palatability. Even during summer, oak seedlings were not eaten as much as trampled by animals seeking shade. He suggested that changing the season of grazing would be an effective means of improving oak survival in grazed pastures. Griggs proposed removal of cattle when the oak commences spring growth and return them after the first fall rains. The results of this study suggest reduced damage during the winter grazing season, which would support Grigg's proposal. While excluding grazing during spring, summer, and fall may be an effective means of increasing oak seedling survival, it severely restricts ranch forage sources if applied to whole ranches or grazing allotments at one time. Consequently, such a practice could only be applied to small portions of a ranch at any one time. 


\section{Conclusions}

Season of grazing had greater influence on seedling survival than the stock densities used in this study. Winter grazing was less detrimental to blue oak seedlings than spring or summer grazing. Seedling survival was greatest for winter grazing.

The contribution of wildlife to reduced blue oak seedling survival in grazed foothill rangelands should not be underestimated when assessing livestock grazing impacts on blue oak seedling damage or survival. There was no difference between browsing damage in the grazed and ungrazed plots for each season of grazing. Furthermore, there was no difference in seedling survival between ungrazed, spring grazed and summer grazed plots.

\section{Literature Cited}

Adams, T.E., P.B. Sands, W.H. Weitkamp, and N.K. McDougald. 1992. Oak seedling establishment on California rangelands. J. Range Manage. 45:93-98.

Bolsinger, C.L. 1988. The hardwoods of California timberlands, woodlands, and savannas. PNW Forest and Range Exp. Sta. Resource Bull. PNW RB-148, USDA Forest Serv., Portland, Ore.

Borchert, Mark I., Frank W. Davis, Joel Michaelsen, and Lynn Dee Oyler. 1989. Interactions of factors affecting seedling recruitment of blue oak (Quercus douglasii) in California. Ecology 70:389-404.

Duncan, D.A., and W.J. Clawson. 1980. Livestock utilization of California's oak woodlands. Proc. Symp. on the Ecology, Management, and Utilization of California Oaks, June 26-28, 1979, Claremont, Calif. USDA Forest Serv. Gen. Tech. Rep. PSW-44. p. 306-313.

Forest and Rangelands Resources Assessment Program (FFRAP). 1988. California's forests and rangelands: Growing conflicts over changing uses. Calif. Dep. Forest and Fire Protection, Sacramento, Calif.

Franco, G.M.M. 1976. Grazing effects on oak distribution in Jasper Ridge and adjacent areas. M.S. Thesis, Stanford University, Palo Alto, Calif.
Frost, William E., Neil K. McDougald, and M.W. Demment. 1991. Blue oak canopy on seasonal forage production and quality. Proc. Symp. on Oak Woodlands and Hardwood Rangeland Management, October 31-November 2, 1990, Davis, Calif. USDA Forest Service Gen. Tech. Rep. PSW-126. p. 307-311.

Georgiadis, N.J., R.W. Ruess, S.J. McNaughton, and D. Western. 1989. Ecological conditions that determine when grazing stimulates grass production. Oecologia 81:316-322.

Gordon, D.R., J.M. Welker, J.W. Menke, and K.J. Rice. 1989. Competition for soil water between annual plants and blue oak (Quercus douglasii) seedlings. Oecologia 79:533-541.

Grimn, J.R. 1976. Regeneration in Quercus lobata savannas, Santa Lucia Mountains, California. Amer. Midl. Natur. 95(2):422-435.

Griggs, F.T. 1986. The ecological setting for the natural regeneration of Engelmann oak (Quercus engelmannii Greene) on the Santa Rosa Plateau, Riverside, County, California. Proc. Symp. on Multiple-Use Management of California's Hardwood Resources. November 12-14, 1986, California Polytechnic State University, San Luis Obispo.

Little, Thomas M., and F. Jackson Hills. 1978. Agricultural experimentation. John Wiley and Sons, N.Y. p. 159-162.

Longhurst, W.M., G.E. Connolly, B.M. Browning, and E.O. Garton. 1979. Food interrelationships of deer and sheep in parts of Mendocino and Lake Counties, California. Hilgardia 47:191-247.

Mayer, K.E., P.C. Passof, C. Bolsinger, W.E. Grenfell, and H. Slick. 1986. Status of the hardwood resource of California: A report to the Board of Forestry. Calif. Dep. of Forest and Fire Protection, Sacramento, Calif.

Muick, P.C., and J. Bartolome. 1986. Oak regeneration on California hard wood rangelands. Trans., W. Sect. Wildlife Soc. 22:121-125.

Sudworth, G.B. 1908. Forest trees of the Pacific slope. USDA Forest Serv., Washington, D.C.

Twisselmann, E.C. 1967. A flora of Kern County, California. Wassman J. Biol. 25 (1 and 2):1-395.

Wagnon, K.A. 1963. Behavior of beef cows on a California Range. Bull. 799, Calif. Agr. Exp. Sta., Berkeley, Calif.

Welker, J.M., and J.W. Menke. 1990. The influence of simulated browsing on tissue water relations, growth and survival of Quercus douglasii (Hook and Arn.) seedlings under slow and rapid rates of soil drought. Functional Ecol. 4:807-817. 